\section{CROONIAN LECTURES} ON

\author{
MIND, BRAIN, AND SPINAL CORD, \\ IN CERTAIN MORBID CONDITIONS.
}

\begin{abstract}
Delivered at the Royal College of Physicians, March 1873 .
\end{abstract}
By C. B. RADCLIFFE, M.D., F.R.C.P.,

Physician to Westminster Hospital, and to the National Hospital for the Paralysed and Epileptic : etc.

\section{LECTURE I.}

Mr. President and Gentlemen,-In the present lecture, my subject will be speculative rather than practical, and yet not altogether without practical bearings ; in the two lectures which follow, I intend to be practical enough-so practical as to make amends for all my shortcomings in that respect now. The actual plan pursued will be to speak, in turn,-on Mind,-on Incipient Insanity,-on a state which is at the bottom of hysteria, hypochondriasis, and other disorders of the nervous system, and to which I propose to give the name of Neuriasis,- on Cerebral Exhaustion,-and on Spinal Exhaustion. The present lecture will be wholly given to the first-named subject; the remaining subjects will be dealt with in the second lecture and in the third.

\section{CONCERNING MIND.}

I find it difficult to sympathise with the disposition to materialise mental phenomena which is so much in accordance with the spirit of the times-the Zeitgeist. I cannot bring myself to believe that mind is resolvable into a function of brain-into mere cerebration; and the more I reflect upon the subject, the more I am indisposed to accept this materialistic view. If I reflect, for example, upon the workings of memory, before long I find myself regarding them from a spiritualistic rather than from a materialistic point of view; and, do what I will, I cannot prevent myself from coming to the conclusion that mind must have its foundation, not in matter, but in spirit, or rather in a central something underlying both matter and spirit. In the limited time at my disposal, it is of course impossible to say much to the purpose upon so wide a subject as mind. At most, indeed, all that is possible is to make a few comments and suggestions, and leave them to their fate without making any serious attempt to fight for them ; and what I now propose to do is simply this and no more, taking memory as my text.

Coleridge, in his Biographia Literaria (vol. ii, p. I I2), relates the case of a girl in which is to be found a very cogent proof that there is something imperishable in memory. "This case," he says, "occurred in a Catholic town in Germany a year or two before my arrival in Göttingen, and had not then ceased to be a frequent subject of conversation. A young woman of four or five and twenty, who could neither read nor write, was seized with a nervous fever, during which, according to the asseverations of all the priests and monks of the neighbourhood, she became possessed by a very learned devil. She continued incessantly talking Latin, Greek, and Hebrew, in very pompous tones, and with most distinct enunciation. This possession was rendered more probable by the known fact that she was a heretic. Voltaire humorously advises the devil to decline all acquaintance with medical men, and it would have been more to his reputation if he had taken this advice in the present instance. The case had attracted the particular attention of a young physician, and by his statement many eminent physiologists and psychologists visited the town, and made cross-examination on the spot. Sheets full of her ravings were taken down from her mouth, and were found to consist of sentences, coherent and intelligible each for itself, but with little or no connection with each other. Of this, however, a small portion only could be traced to the Bible; the remainder seemed to be in the Rabbinical dialect. All trick or conspiracy was out of the question. Not only had this young woman ever been a harmless, simple creature, but she was labouring under a nervous fever. In the town in which she had been resident for many years as a servant in different families, no solution presented itself. The young phy sician, however, determined to trace her past life step by step; for the patient herself was incapable of returning a rational answer. He at length discovered a place where her parents had lived; travelled thither, found them dead, but an uncle surviving, and from him learnt that the patient had been charitably taken by an old Protestant pastor at nine years old, and had remained with him some years, even to the old man's death. Of this pastor the uncle knew nothing but that he was a very good man. With great difficulty, and after much trouble, our young medical philosupher discovered a niece of the pastor's, who had lived with him as a housekeeper, and had inherited his effects. She remembered the girl; related that her venerable uncle had been too indulgent, and could not bear to hear her scolded; that she was willing to have kept her, but that after her patron's death the girl herself refused to stay. Anxious inquiries were then, of course, made concerning the pastor's habits, and the solution of the problem was soon obtained. For it appeared that it had been the old man's custom for years to walk up and down a passage in his house into which the kitchen door opened, and to read to himself, with a loud voice, out of his favourite books. A considerable number of these were still in the niece's possession. She added that he was a very learned man, and a great Hebraist. Among the books were found a collection of Rabbinical writings, together with several of the Greek and Latin fathers; and the physician succeeded in identifying so many passages with those taken down at the young woman's bedside, that no doubt could remain in any rational mind concerning the true origin of the impressions made upon her nervous system."

"This authenticated case," continues Coleridge, "furnishes both proof and instance that reliques of sensation may exist for an indefinite time in a latent state in the very same order in which they were originally impressed, and contributes to make it even probable that all thoughts are in themselves imperishable; and that if the intelligent faculty should be rendered more comprehensive, it will require only a different and apportioned organisation - the body celestial instead of the body terres. trial - to bring before every human soul the collective experience of its whole past existence. And this-this, perchance, is the dread book of judgment in whose mysterious hieroglyphics every idle word is recorded ! $\mathrm{Yea}$, in the very nature of a living spirit, it may be more probable that heaven and earth shall pass away than that a single act-a single thought-shall be loosened or lost from that living chain of causes, to all whose links, conscious or unconscious, the free-will, our only absolute self, is co.extensive and co-present."

As bearing directly upon these remarks of Coleridge, De Quincy also says : "I was once told by a near relative of mine (a woman of masculine understanding and unimpeachable veracity) that, having in her childhood fallen into a river, and being on the very verge of death, but for the assistance which reached her at the last critical moment, she then saw her whole past life, clothed in its forgotten incidents, arrayed before her as in a mirror, not successively, but simultaneously; and that she had at the same time a faculty developed as suddenly for comprehending the whole and every part. This, from some opium experiences, I can believe. I have, indeed, seen the same thing asserted twice in modern books, and accompanied by a remark, which is probably true-viz., that the dread book of account which the Scriptures speak of is, in fact, the mind itself of each individual. Of this at least I feel assured, that there is no such thing as ultimate forgetting; traces once impressed upon the memory are indestructible. A thousand accidents may and will interpose a veil between our present consciousness and the secret inscriptions on the mind. Accidents of the same sort will also rend away this veil. But alike, whether veiled or unveiled, the inscriptions remain for ever: just as the stars seem to withdraw before the common light of day, whereas, in fact, we all know that it is the light which is drawn over them as a veil; and that they are waiting to be revealed whenever the obscuring daylight itself shall have been withdrawn."

Instances pointing to the same conclusion might readily be multiplied, but the two which I have culled from the pages of these classical writers are of themselves sufficient to make it much more than probable that the records of memory are indelible, that it is the power of reading the obscurer passages which is alone wanting now, and that this power will not always be wanting. And if this be so-and that it is so is to me a conviction not less certain than that which testifies to my own existence - then memory becomes altogether unintelligible, unless it be supposed that the mind of which it is a faculty has its foundation, not in perishable and ever-perishing brain, but in something, perhaps a spirit, of which imperishability may be an attribute.

There is also good reason to believe that the records of memory are not all preserved within the body-that some of them have been noted down elsewhere. The knowledge of identity, by which a thing once seen is recognised as having been seen, is a reason for believing that this thing retains in itself some mark by which it can be recognised. Without such mark any knowledge of identity, any act of recognition becomes impossible, inasmuch as every fresh impression of the same thing must strike upon the mind as something new and different. To me, indeed, the knowledge of identity which is involved in the act of 
recognition is in itself, and by itself, a conclusive proof that the records of memory are not all kept in the ganglionic brain-cells-that some of them are to be found elsewhere; nay, it even suggests the idea that these latter may be the originals of which the former are only copies at most, copies, too, which may perhaps be dispensed with. For, after all, if mind be a spirit, what is within and what is without in relation to it? If heaven be within me-and I cannot doubt the authority for so believing - then surely the world in which I live is not beyond me. And if mind be a spirit, this idea is not altogether unintelligible ; for spirit is in essence precisely that which is not hemmed in by bounds like body. If mind be a spirit indeed, it must have the capacity of embracing all things, of including all things. If mind be a spirit, it may for that reason be in very deed ubiquitous. And thus there is no need that the records of memory should be copied in the ganglionic brain-cells, all that is wanted being that they should remain wherever they were originally written down, no matter where; for, by virtue of its faculty of ubiquity, it is as easy for the mind to find them in one place as in another. Nay, it must be more easy for the mind to find these originals than the copies in the perishable and ever-perishing brain-cells. How can a record which is indelible be written upon a tablet which is no more constant than a drop of water at a given point in an ever-flowing stream? What never-ending work for the recording angel or other agent whose hard task, according to this view, it is to keep this record. Surely, no demand can be made upon credulity more incredible than this. And yet it is this very demand which is made when it is supposed that the records of memory are stored up in certain brain-cells. Moreover, to suppose that memory has its seat in these cells is to attribute to the very simplest and crudest of organic forms the most exalted of functions- to make a demand upon credulity almost as great as that which is required to see, potentially, man him. self, body and mind, in a marine ascidian, which creature is little more than a large simple cell. No doubt these ganglionic brain-cells have some all-important function to fulfil in relation to memory and every other mental faculty, but it does not follow that this function is that which it is assumed to be. It may be, indeed, that they have to help in keeping up that electrical state of the brain and of the nervous sys. tem generally without which mental action of any kind could not take place at all - that the brain and the rest of the nervous system is a wonderful telegraphic apparatus by which the mind communicates with its own body and with other bodies; or it may be that they have some other function, equally essential, which has yet to be discovered; but be this as it may, after what has been said, it is difficult for me to believe that their function can be that of storing up within themselves the records of memory. After what has been said, indeed, the difficulty is rather not to believe that memory has its seats anywhere and everywhere, wherever the mind may have roamed; that, once made and appropriated, these seats are never abandoned; and that it is by the mind being always upon them, and awaking or remaining awake, not by reading any words or signs or symbols written upon them, that the memory acts, what is remembered coming back, as it does in fact, as a scene. At all events, the fact that a thing outside the body, once seen, is recognised as having been seen, is to me a reason for believing that the memory relating to it is, in part at least, lodged in it; and thus it is that I am left free to conclude that the mind, of which memory is a faculty, may range beyond body as a spirit may be supposed to rangethat mind, indeed, may be a spirit, of which one attribute is ubiquitous. niss.

This view of mind, as gathered from the history of memory, would also seem to derive no small degree of countenance from the light it sheds upon more than one recondite mental question.

If mind be a spirit, and if memory testifies to the immanence of this spirit in the things remembered, wherever these may be, no matter whether without or within, then once to know a thing is always to know it, and this act of recognition ceases to be separable from the act of cognition. Upon this view, a thing once seen from that time re. mains part and parcel of the spiritual being of him who sees it; and it must be recognised, if seen again or remembered, without any question being raised as to its identity. Once held it is never let go ; and by ever holding it, the mind wants no other proof of its identity.

Again, the view here taken of memory is not a little supported by the light it sheds upon the association of ideas; for if the mind remain wherever it has roamed, never vacating territory once occupied, does it not follow that the subjects or objects appropriated must ever remain in that particular relation to each other which they occupied when first appropriated; so that for the memory to go back along any one chain of thought to any one link in that chain is of necessity to bring to the mind's eye the overlappings of the adjoining links?

Again, in this view of memory there is what would seem to be a sort of explanation of the strange backward way in which memory fails as old age advances and under the ravages of certain diseases. In this failure recent events are forgotten first, then those which are less and less recent in turn, until at last all that is remembered is that which happened long long ago. Very recently, for example, I saw a French lady whose case supplies a memorable instance of the way in which disease may act in this manner-the case being one of relapsing mania, with epileptiform symptoms, rapidly passing into dementia. Until she reached her sixteenth year, this lady lived in France and spoke only French; after this she came to live in England, and began to speak English. When about twenty she married an American; and from this time for the next twenty years she lived sometimes in America, sometimes in England, speaking English habitually, and French scarcely ever. About two years ago, when I saw her first, her mind was feeble, and that was all; four months ago, when I saw her last, she had forgotten everything connected with her married life, her English not excepted; and if asked who she was and where she was, she gave her maiden name, and mentioned in French the street in Paris where she had lived when a girl. So completely had she forgotten her English, and gone back to her French, that it had become necessary to change an English for a French maid. What happened in this case, and happens in cases of the kind, as well as in old age, is the very reverse of what might be expected to happen. It might be expected that the memory of early events would be the first to fade, and that of recent events the last ; but in reality there is no good ground for this expectation. So far from this being the case, there is indeed reason for believing that that which actually happens is precisely what might be expected to happen. It is possible, regarding it as a spirit, to believe that mind goes on expanding through a series of concentric circles until it reaches its maturity, and that, so long as it retains its full vigour, it retains its hold upon the memories in each of these circles, inner and outer ; and that afterwards, when a contrary movement to that of development is taking place, the mind, as it were, falls asleep in circle after circle in which it had previously kept awake, until at last it only remains awake in the innermost circles of all, and that in this way the memories of recent events, which are in the outer circles, will be the first to fade, and those of early events, which are in the inner circles, the last. That would happen, in fact, which is really found to happen; and thus, what seemed to be so very unintelligible at first, becomes not altogether inexplicable when it is more clearly looked into.

Upon this view of mind, also, it seems to be possible to not a little simplify the operations of mind, so far as the nerves are concerned, in the processes of muscular motion and sensation. If the mind be not in brain exclusively, but in the muscles and in the organs of sense, it may act upon the muscles and be acted upon by the senses directly; and the nerves may have nothing to do in the matter except to serve as telegraphic conductors between distant parts of the organism which must be kept in communication, and as parts of a nervous system one of whose functions is to keep up an electrical condition without which any form of mental manifestation would be impossible.

And thus memory may show - and that, too, in no unequivocal man. ner-that the mind of which it is a manifestation is something more than a function of certain brain-cells, something more than a mere mode of cerebration, by showing that mind can have no less unsubstantial a foundation than that which can only be supplied by a spirit which is at once imperishable and ubiquitous in its essence. Nay, it is possible to find in memory, in addition, certain reasons for believing that the spirit of which mind consists is endowed, not only with imperishability and ubiquitousness, but with what, without any great stretch of fancy, may be looked upon as a creative power; for may not the particular ideas with which the memory is stored have their origin in a kind of fat on the part of mind akin to that by which, according to Revelation, all things were called into existence in the first instance?

Nor is a different conclusion to be drawn from the stories told of mind by other mental faculties. On the contrary, each and all of these faculties -as it would not be difficult to prove if I had only time to do it inpoint, beyond body, to a spirit wondrously endowed with various gifts ; imagination to a spirit absolutely superior to time and space, and having also a creative faculty ; will to a spirit endowed with almost indomitable energy ; intellect to a spirit of intelligence which grasps at all things, and scarcely fails to comprehend them ; conscience to a spirit recognising the absolute supremacy of truth and justice and goodness; the reli. gious instincts to a spirit which is capable of seeking and receiving Divine help ; the conviction of personality to a spirit which is, not a vague essence, but an actual person.

The story told of mind in these several ways, indeed, is the same in substance as that told by memory. It is, that mind must have for its basis not body merely, but spirit endowed with divine attributes. It is a story, in short, which tallies well enough with that told in the Scrip. tures-that man was created in the image of God, even of Him who is 
invisible, self-existent, eternal, omnipresent, omniscient, almighty Spirit, who is perfectly just and true and holy, and who is at the same time the very cause and substance of all things ; and that man's present state is not this, but one in which this divine image is marred at best and sometimes obliterated-which tallies with this story rather than with that in which man is regarded as having originated in a marine ascidian, or in a creature still lower down in the scale of being, and as having risen to his present position, ever ascending from a lower grade to a higher through many different forms of being-first brute, then humanby a process of evolution, dependent upon his own aspiring efforts in the main, which efforts have had to be carried on with weariness and uncertainty through countless ages. Upon the former view, as it seems to me, something is really gained in the interpretation of mind; upon the latter view, nothing, or even less than nothing, if that be possible. But I shall be better able to discuss this question presently ; and here, therefore, I will only repeat what I have already said-namely, this, that the story of mind told hitherto is not intelligible enough if man have that spiritual nature which he is declared to have in the Scriptures.

Nor is there even in body a flat contradiction to these soaring notions respecting mind. The visible body is certainly a transitory phenomenon : the matter of which it is made is ever changing, never abiding. Something abiding there is, no doubt, or the visible body could not continue in existence ; but that something cannot be that which meets the eye. And if that which remains is not this, what is it? Is it spirit? Is it, in short, an archetypal form, a spiritual body, the body celestial to which Coleridge alludes in the quotation already given? May it be that this archetypal form, this spiritual or celestial body, is made manifest to the eye by matter passing across it, and being illumined in passing, as a ray of light through a dark room is made visible by the illuminated motes of dust floating in it? Like the appearance which went before the Israelites of old, in a pillar of cloud by day, and in a pillar of fire by night, may it be that the visible body hides rather than reveals the real presence and person within it? Is the natural visible body capable of a transformation by which the ties of earth may be so unloosed as to allow it to float in air or walk on water, or become actually invisible, without losing the capability of again becoming visible - a transfiguration by which, as a spirit, it may be anywhere in a moment, not by becoming mere disembodied spirit, but by becoming spirit capable of embodiment wherever it may be, anywhere, everywhere? If there were time for the search, it would not be difficult to find much to justify an affirmative answer to each of these questions. As it is, all that $I$ can do is to say that the visible body must have its foundation, like mind, not in mere matter, but in spirit ; that there is nothing in the body, philosophically regarded, to contradict this conclusion respecting mind; nothing, in short, to contradict the view which regards man as having a spiritual nature, which is the image of the Divine Spirit, and which explains his various powers, bodily and mental alike, as gifts, which are now in great measure withheld, because man will act, practically at least, as if he were independent of the Giver.

Taking this view of mind and body, it is easy to find a deep meaning in the grand old tale of him who slew the Gorgon and won Andromeda as a bride. For what is the gist of this story? Perseus triumphs, not by his own unaided earthly might, but by gifts from on high, by which his body is transfigured, spiritualised, dematerialised, energised. $\mathrm{He}$ receives the polished shield of Pallas Athené, the cap of Pluto, the winged sandals or talaria, and the diamond-bladed weapon, herpé, of Hermes. Shod with the sandals, he is emancipated from the material ties which bound him to earth or dragged him under water; and he can move as he lists, with the freedom of a spirit, over earth and sea, without touching either, but he is still visible. Covered with the cap, this emancipation from the material world is still more complete, and he becomes invisible-invisible, yet visible as before the moment he uncovers himself. Armed with herpé, with equal ease he beheads the Gorgon, or severs the adamantine chains which bind Andromeda to the rock. In order to kill the Gorgon he must be thus shod, covered, armed ; and, besides all this, he must use his shield : he must look only at the image reflected there, and direct the stoke of herpé accordingly. A single glance at the Gorgon herself, and at that very moment he becomes stone. And why? Is the eye to be turned away from this beautiful terror in order to signify that the visible material object must not be mistaken for the invisible spiritual substance which alone is real, and that not to turn the eye away is to mistake matter for spirit-a mistake which may be said to materialise or turn into stone the observer? Is the eye to be turned away from the face of Medusa to its reflection on the shield, in order to signify that the distinction of within and without is a blunder not less compromising than that which mistakes spirit for matter; that there is no without so far as the mind is concerned, and that objects which, judged only by the eye and the senses, seem to be without, are really comprehended within the all-pervading spiritual being of the observer?

There is a strange fascination in these old stories, and the fancy is very apt to run away with the reason in dealing with them. Still, after what has been said, there can be no great difficulty in bringing the reason to accept this particular interpretation : after what has been said, indeed, the difficulty is rather to find another interpretation which may be acceptable. And yet a full half of what might have been said to the same effect remains unsaid-namely, that of which the material is to be found, not in profane philosophy, ancient or modern, or in profane poetry, ancient or modern, but in sacred philosophy and poetry. Nay, that which remains unsaid is much more than the full half of what might have been said, for it is not too much to say that the grand proofs of the view of mind and body which has been taken are only to be found in sacred philosophy and poetry. But this is a part of my subject upon which I must not enter here, though, as will be well understood, in refraining from doing this I omit arguments of the weightiest sort in favour of the conclusions at which I have been compelled to arrive. As will be well understood, I say-for it must be familiar to all that this philosophy and poetry is full of statements which are absolutely meaningless if there be not a divine spirit in man whose office it is to do all the work of mind, and if the body or flesh be not capable of spiritualisation.

Having arrived at this conclusion, it is impossible for me to have much sympathy with certain views which have found much favour in many quarters, and upon which, before coming to a close, I would wish to say a word or two, less with the intention of controverting them, than for the purpose of showing that I have not overlooked them. I might make many references : I content myself by referring to the views with which the names of Auguste Comte, Mr. Herbert Spencer, Professor Bain, and Mr. Darwin are associated.

The positive philosophy of Comte is not to be easily disposed of in few words. Its author seens to call it positive because he regards all other philosophies as negative, or negative in their results, at any rate ; at least, this is a not unfair inference from the temper in which many of his disciples, the positivists, as they have come to be called, are apt to bring it forward. Master and disciples alike believe strongly. And what do they believe? Fundamentally this. The world is made up of matter, and the forces which are immanent in matter. Beyond these phenomena of matter and material force nothing is known, or to be known, and even this possible knowledge is not absolute, but relative. Everything divine, everything metaphysical, is repudiated ; no attempt is made to look into the essence of things, or to deal with ultimate causes, whether efficient or final ; and all that is done is to study phenomena in themselves and in their mutual relations, with a view to discover their laws, which laws are the constant sequences which unite them as antecedent and consequent. Beyond matter and material force, then, the positivist philosophy knows nothing, or if a step further is taken, it is from force to matter, rather than from matter to force. Matter, it is held, is in all cases endowed with certain physical properties; chemical properties are developed by a binary combination of matter: vital properties come into existence when matter enters into more complicated combinations. All vital manifestations are no more than physical actions arising necessarily in particular organisations. The mind is nothing more than cerebration, and this or that system of phrenology supplies the key which will unlock all its mysteries. A physical basis, la physique sociale, is also found for the phenomena of social life. Just as the life of an individual man is supposed to result from certain physical changes in the organism belonging to that man, so the life of a community, social life, is supposed to be equally dependent upon certain physical changes in that larger organism (so to speak), in which many men form component parts. La physique sociale supplies the explanation of all that is mysterious in social life, doing for this life all that is done for the life of the individual by (to coin an analogous expression), la physique individuelle. All a priori reasoning from any abstract axiom is looked upon as purely chimerical : all reasoning must be founded on actual observation. All phenomena are regarded as subject to invariable material laws: and the sole object of positive philosophy is to discover these laws, and to system. atise them in the direction of unity-to regulate by reducing them to one single law. One grand law, which Comte claims to have discovered, and apon which he bases his demonstration in many parts of his grand argument, is this-that there is an inevitable order in the discovery of truth, testified to by the history of mankind, no less than by that of individual man, by which the view taken of truth is first theological or fictitious, then metaphysical or abstract, then scientific or physical, or positive. A theological view of things is that which serves as the necessary starting point in the movement of the human intelligence. In this infantile condition, the mind grasps after primal 
and final causes, and all phenomena are referred to the direct and arbitrary interference of supernatural agents, more or less numerous at first, and of one grand agent at last, so that monotheism is the climax of development in this way of thinking. To this follows the metaphysical view of things, in which abstract and orderly forces are made to take the place and do the work of the arbitrary supernatural agents, which haunted the fancy before theological trammels were shaken off. The grand generalisation of nature, in this way of thinking, corresponds to that of monotheism in the former way. Last of all, in the maturity of the intelligence, comes the physical positive way of looking at things, in which everything metaphysical, no less than everything theological, is given up as mere child-play, with which manly intelligence can have nothing to do. Comte himself says, man is "théologien dans son enfance, métaphysicien dans sa jeunesse, et physicien dans sa virilité," and adds, that all men "au niveau de leurs siècles," may verify this for themselves, if they will, in their own experience. Do what I will, however, I cannot bring myself au niveau de mon siècle. I cannot bring my mind to give up metaphysics and theology, and to believe that "whatever for man is true men can verify." Nor can I believe that the history of mankind, or of individual men, justifies the conclusion that the mind of man develops in a way which associates theology and metaphysics with states of comparative ignorance. Often, I am sure, the order of development is the reverse of this, men who, without knowing it, perhaps, were practically positivists to begin with, becoming dissatisfied with speculating upon phenomena and their laws, and ending by taking metaphysical and theological views of everything. And certainly Comte's own history is in flat contradiction to the doctrine in question. $U p$ to a certain point he is positive enough ; further on, as his later writings sufficiently prove, the objective synthesis of his positive philosophy does not content him, and he must have a subjective synthesis, and even a religion of a certain sort, with a most complicated cultus-a subjective synthesis, in which the most unselfish love, altruism in place of egoism, figures as the law of laws to be evolved. He passes from physics, that is to say, on into metaphysics, but he can scarcely be said to have passed on beyond metaphysics into theology, for though he has a religion of a sort and a complicated cultus, he still holds the same negative attitude towards God-the Grand Etre of which he talks being no more than an impersonal abstraction, which he makes for himself as an object of adoration, out of all the good qualities of all men, in all times, together with certain additions derived from pet dogs, and other beasts, which possess any good qualities. But it really does not matter whether Comte himself remained a consistent positivist throughout his life or not. The question is, whether this positive philosophy, as professed by the positivists, now renders it necessary to reconsider the conclusions already arrived at respecting mind and body, and this question is soon disposed of. For what is the case? Matter is all in all. The several manifestations of mind are only different forms of cerebration, localised according to the rules of this or that form of phrenology. And therefore the question remains where it was, the answer to this positivist view being simply that which is applicable to any materialistic view. Indeed, instead of becoming a convert to positivism I feel compelled to take up a position in antagonism to it, and to suppose that brain has its origin in mind rather than that mind has its origin in brain. The elements of living brain cannot be kept together without life; of this there can be no doubt; and, if so, then the very foundations of the notion that mind is a mere function of brain, mere cerebration, are swept away. For what holds good of the relations of simple life to brain must hold good also of the relations of mind to brain, mind being only life in its fullest manifestation. And thus I fail to find anything in the positive philosophy to make it necessary to set aside, or even to qualify, any of the conclusions respecting mind and body to which I have been led by the course of the argument hitherto.

Nor am I disposed to abandon these conclusions and become a disciple of Professor Bain. Mind, Dr. Bain holds, objectively as well as subjectively, is made up of feeling, intellect, and will. By the side of all mental phenomena there runs a line of physical causation. The two worlds, mental and physical, must stand or fall together. Mental phenomena are as subject to absolute law as physical phenomena, and as incapable of irregular action. As with the physical, so with the mental, under the same circumstances there must be precisely the same consequences. The power to act voluntarily upon the muscles, or in any other way, is in reality no independent power; the act, when thoroughly looked into, is only a reflex phenomenon, in originating which the feelings have much to do. Free will, however exercised, whether in choice, deliberation, self-determination, moral action, responsibility, or in any other way, is nothing more than a delusion engendered in self-conceit, the will being as much the subject of law, and as little entitled to freedom of any sort, as the feelings and the intelligence. Even the conviction of personal identity must be got rid of in the same manner, this, like the will, being lost in law. But surely a view like this cannot be otherwise than unsatisfactory in the fullest sense of the word, if what has been said upon mind have any claim to be regarded as probable. It is materialistic, with all the shortcomings of this view, and it supplies no real explanation of what it professes to explain. It supplies no real explanation, for what is gained by saying that mind is made up of feelings, intellect, and will, and by describing the various ways in which these act and react upon each other, in turn, as cause and effect? Such description is full of interest, without doubt ; but when it is made $I$ am as far as ever from understanding why I feel, why I reason, and why I will; and the more I reflect upon the subject, the more unwilling am I to explain myself, feelings, reason, and will, as a highly complicated mechanism, which is set to go in various ways, but which must always go in the same way if set to go in the same way. There is that in me, indeed, which altogether repudiates a view so mechanical, and with this remark I may content myself, for I have already said enough to show why I do this, and what view I would substitute for it.

With Mr. Herbert Spencer I have much sympathy, and yet I cannot be content to stay at the end at which he arrives and stays. I thoroughly sympathise in his belief that all true philosophical reasoning has its end in unity - that there are abundant proofs of this unity in matter and spirit, in things visible and things invisible-that the truths of science and religion find reconciliation in this unity. I reject, as he does, a purely spiritualistic view of things, no less than a purely materialistic view. But I cannot agree with him in believing in indefinite evolution. Nor can I agree with him in believing that life and mind are to be interpreted in terms of matter, motion and force, even though this interpretation be taken as only symbolising provisionally arbitrary aspects of an Unknown Reality; and, least of all, can I agree with him in believing that the principle of unity, underlying matter and spirit alike, is merely an Unknown Cause, the Unknowable, a Power without limits of either time or space, of which the nature ever remains incon. ceivable. Much, no doubt, is of necessity unknowable, but I would not place the limits of thought where Mr. Spencer would place them. On the contrary, I would hold that there is nothing unreasonable in widening these limits so as to bring within them an actual God, even the God of the Scriptures, and that by so doing a much more reasonable realisation of unity is to be found than that which can be found in an Unknown Reality. I would hold, indeed, that the nature of the Unknowable is to be encroached upon in this way, and to this extent, by the power of the reason, and also that there is nothing in the speculations to which I am now referring which can stamp as unreasonable that particular view of mind and body which it is the object of this lecture to set forth cursorily.

But what of that view of mind which arises out of the doctrine with which the name of Mr. Darwin is at present especially connected ?-a name which must always command the highest respect of all naturalists. Is not the view arising out of the doctrine of evolution altogether at variance with that which I have been led to take in this lecture? Unquestionably so. It is simply impossible to reconcile the two views; and it is also certain that if that which arises out of the doctrine of evolution be right, the other must be abandoned. What, then, are the facts upon which this doctrine of evolution is based? This is the question. Are they to be read only in favour of this doctrine, or is there another reading? I venture to think that there is another reading; but how can I make good this statement with the hands of the clock standing where they do? At most I can only throw out a hint or two of what I might say on the subject it I had the time, and this is all $I$ propose to do.

No one can believe more firmly than I do that there is a common plan in all animals and in all parts of animals, as well as in all plants and in all parts of plants; or that there is a common unity for the whole organic world, plant and animal alike. No one can believe more firmly than I do that there are manifestations of mind, not dissimilar in kind to human mind, in the brute creation; and that the law of mind is one and the same everywhere. But it does not follow from this belief in unity that I should believe that one organ should be deve. loped into another organ, or one animal or plant into another animal or plant. The doctrine of unity is quite as consistent with a belief that there are certain fixed differences in organs or organisms; it has nothing to do with the doctrine of evolution, except, perhaps, in making its acceptance a little less difficult; for it is a little more easy to suppose that a higher creature may be evolved from a lower, if there be the same archetypal unity of plan underlying the two. More than this it cannot do.

I cannot doubt that in the embryonic life of the higher animals there is a process of development at work by which the embryo, before 
arriving at maturity, passes through certain stages which seem to shadow forth certain permanent states of being lower down in the scale of life. I cannot doubt that in this case the more perfect is preceded by the more crude, and that there is a process of evolution at work up to a given point. But what follows? Certainly not this-that these resemblances are realities; that the embryo of a higher animal, in developing to maturity, passed through a succession of different animals, each one a little more perfect than its predecessors. Certainly not more than this-that the higher animal, in the embryonic period of its history, without ever ceasing to be itselr, passes through certain stages of development, in which there are. certain likenesses, never very close, to certain forms of animal life lower down than itself in the scale of being-likenesses which simply bear witness to the unity of plan in all forms of animal life.

I also find it difficult to twist the marvellous improvability of man into an argument for the doctrine of evolution. Who shall say that this improvability is not restricted within certain prescribed limits? As yet man, in his struggle for life, has never turned his opportunities of natural selection so far to account as to make even the slightest advance towards physical improvement. And it is possible that the change for the better which is actually witnessed in man may have to be explained in accordance with the Scriptures, tather than in accordance with the doctrine of evolution.

Nur can I rest satisfied with what may be spoken of as the more special evidence in favour of evolution. The pigeon, by developing under cultivation into what may be considered as improved varieties of pigeon, may at first seem to be the subject of evolution; but the changes produced in this way are never more than those minor changes which go to make up the differences called varieties-never so great as to constitute another species of bird. Moreover, only let the varieties thus produced be let alone for a few generations, and the inevitable result is a return to the original form of common pigeon, if not to that of the wild blue rock-pigeon. The history contradicts the notion of evolution, rather than confirms it. And so with the dog or any other animal which may be modified as the pigeon is modified; the change produced is never beyond that of mere variety, never into that of a new species; and let the constraining influences which brought it about come to an end, and, as with the pigeon, it is not long before the original wild form has again cropped out. And what other conclusion can be fairly drawn from the infertility of mules than this-that there is a barrier between different species of animals, even between those which are most closely akin to each other, by which one is prevented from passing into the other? Nay, it is even difficult to find any evidence in favour of evolution in the history of the rudimentary creatures which swarm in dense crowds around the very feet of the scale of being.

- Here are wonderful changes at work, by which, as Dr. Bastian so clearly demonstrates, bacleria, the simplest of all living units, may be developed, possibly from inorganic elements, almost at the will of the experimenter, into monads and amaba and paramecia, or into the lowest forms of fungus -into forms of animal life, that is to say, or into forms of vegetable life; but not much is to be built upon this fact in favour of evolution. For what follows? Simply this-that these forms are unstable in the highest degree; and that, instead of passing on into higher forms of being, they presently again break up into their original bacterial units, which units are destined again and again to go through the same narrow round of combining and separating. The evolution, if evolution it be, is kept within the narrowest limits; the tendency to retrograde is quite as marked as the tendency to go forwards; and, as respects evolution, the conclusion to be drawn is even that which has been drawn from the changes witnessed in the pigeon and the dog - this and no other.

It may be questioned, also, whether this doctrine of evolution derives as much support as it is supposed to do from the facts belonging to 2stronomy and geology.

The nebular hypothesis, which may be taken as the real startingpoint of the doctrine in question, is certainly very nebulous. The facts upon which it is founded show unity of plan; of that there need be no doubt. But this unity of plan is really a matter quite apart from the nebular hypothesis founded upon it. Besides, where did the heat come from which kept up the nebulous state which preceded the formation of the heavenly bodies of various sorts? and what has become of it since the time of this formation? What real proof is there of the continual cooling which should still be going on according to this vicw? Lilke light and gravity, heat may result in the mutual reactions of the heavenly bodies, or be a property of one or other of these bodies ; but to conceive of it as independent of these bodies is, to say the least, no easy matter. Indeed, so difficult is it so to conceive it, that, until the difficulty is overcome, the nebular hypothesis may be set aside as a dream which is as little calculated to give probability to the doctrine of evolution as the evidence which has been already glanced at.

And so likewise with that particular evidence in favour of evolution which the facts of geology are supposed to supply. Endless ages are needed to allow of evolution; and the facts of geology are believed to testify unequirocally to the lapse of these ages. But is it so? If the rock in which the skeleton of a plesiosaurus is embedded had been deposited as slowly as it is supposed to have been deposited, every trace of organisation must have decomposed and disappeared long ages before the animal could have been covered up in its bed. For the skeleton to be there at all, indeed, is a plain proof that the rock, at least to the thickness needed for embedding it, must have been deposited before decomposition had time to do its work fully. And so likewise in every other analogous case. Nay, it may even be questioned whether there has been a separate upheaval and sinking to allow of the formation of each coal-seam or limestone-bed ; for many of these seams and beds which are parallel may have to be explained as drifs, which have to do with one cataclysm of upheaval and sinking rather than with many such cataclysms; for how could this strict parallelism be preserved if there had been many cataclysms? Moreover, it must not be forgotten that there are not a few fossils out of place in the strata - Iossils which ought not to be where they are if living things had made their appearance on the earth in the order required by the doc. trine of evolution.

In a word, I fail to find anywhere sufficient reason for believing that man began his history as a marine ascidian, or as a creature still lower down in the scale of being, and that he has worked his way to his present state of civilisation by ceaseless strugglings upwards-first, in countless forms of brute life, each one succeeding in the series being a little more advanced than that which went before it, and then through an interminable line of savage ancestry, of which the first in the series was only a shade more advanced than the tailless ape of which he was the immediate descendant. And glad I am that it is so; for this idea of imperfect being, ever, and almost for ever, straining after perfection, and constantly failing in the struggle, produces a feeling approaching to a painful shudder. At any rate, until these and other difficulties are swept away, I find it more easy to accept the doctrine of creation than to accept the doctrine of evolution, and to believe that each creature was created perfect in itself, and in its relations to all other creatures and to the universe of which it is a necessary part-so perfect as to deserve to be spoken of at the beginning as "very good"; and that man originally was no brute-descended savage, living in a wilderness, and fighting his way step by step upwards to a higher level, but a demigod, walking and talking in a paradise with the God in whose image he was made, until, for some fault of his own, he was driven out into the wilderness, a slave to body, naked, and all but altogether oblivious of everything relating to his high original. This view, I honestly believe, is the more reasonable of the two; and with this confession, without saying more in its support, I will abruptly bring to an end the roundabout remarks into which $I$ have been led by the wish to say something to the purpose concerning mind.

But why, it may be asked, have I dwelt so long upon this subject? Why at all in this place? Partly because I believe that to all men, to physicians most of all, the subject is of supreme interest speculatively ; partly because I am sure that it has very important bearings upon the actual practice of medicine. I believe most fully that a low material. istic view of mind is mischievous in a thousand ways in the practice of medicine. It places the physician in a wrong attitude to begin with, in that, too often at least, it leads him to regard his patient as a piece of admirable mechanism which comes to pieces and is done with at death ; while at the same time, reacting upon himself, it is of necessity not a little calculated to make him callous and unmindful of the high responsibilities of his office. The more, indeed, I see of disease, the more I am satisfied that it is a very grave error to ignore the action of mind upon body both as a cause of disorder and as a remedy for itthe more I am convinced that mind even now-even now, for now, so far from possessing its full powers, mind must be looked upon as in great measure paralysed, demented even, in a morbid rather than in a healthy condition, so that, after all, in treating of mind in its present condition, I am keeping to the promise in the title of these lectures, namely, to speak of mind in certain morbid conditions-even now, I say, I am convinced that mind is the master of the body rather than the slave. No doubt the body reacts on the mind most prejudicially ; but scarcely ever does the mind fail to assert its mastery in some unmistakable way, though not always very loudly. Indeed, the familiar fact that 2 hopeful patient will go on living long after his body has become diseased to an extent which would seem to be more than sufficient to kill, and that a hopeless patient will die with little or nothing the matter with him, so far as mere bodily disease is concerned, is of 
itself sufficient to establish the position that mind is the master of body rather than its slave; that the body droops or revives because the mind hes or has not given in, rather than on account of any changes in itself; and to make it probable that a primary indication, as well in the prevention as in the treatment of disease, bodily no less than mental, is to put in order as far as possible the mental condition of the patient. In the next lecture, perhaps, I may find occasion to speak a little more particularly on this subject : now I can but bring my present lecture to an end by making these broad statements.

\section{ABSTRACT OF THE GOULSTONIAN LECTURES}

\section{ELE PHANTIASIS GRECORUM. Delivered at the K'oyal College of Physicians, 1873.} B Y R O B E R T I I V E I N G,, M.D.,

\section{LECTURE III.}

THE identification of leprosy as a distinct disease has been beset with difficulties. Up to a late period it was confounded with several other disorders, such as the Barbadoes leg, syphilis, and scurvy. By some it was supposed that certain local maladies, such as the radesyge of Norway and the pellagra of Lombardy, were only different varieties of leprous affections; and it was even believed for many years that the leprosy of Iceland and Madeira respectively, and the spedalsked of Norseland, constituted distinct species from elephantiasis Græcorum. All this of necessity led to much confusion; and not until Drs. Danielssen and Boeck had visited the eastern shores of the Mediterranean was the question finally set at rest, and the identity of leprosy in all parts of the world fully established.

At the present day, leprosy is universally recognised as a constitutional disease, sui generis, and manifesting certain well marked and characteristic features. It is especially a malady of young adult life ; yet no period from infancy to old age is entirely exempt from it. Dr. Vandyke Carter was one of the first of our countrymen to describe accurately the three principal forms assumed by elephantiasis Græcorum, namely, (I) the macular, (2) the anzsthetic, and (3) the tuberculated. These three forms are often only different phases of the same disease, and are sometimes seen coexisting in one and the same individual. Nevertheless, in typical cases, their clinical features are sufficiently distinct to justify the nomenclature now usually adopted.

The Premonitory Stage. - The early stage of leprosy is characterised by lassitude, and a sense of bodily and mental weariness and depression, without any assignable cause. These symptoms last for an uncertain time, which may be measured by weeks or months, and are usually accompanied or followed by slight rigors, loss of appetite and nausea, with occasional nocturnal febrile attacks, and other unequivocal signs of general constitutional disturbance. After a time, this is followed by what Danielssen and Boeck call the "periodically eruptive stage", in which an acute eruption breaks out on different parts of the body, the skin of which becomes red, swollen and tender in patches. After a few days or weeks, these blotches subside, but often leave behind a patch of brown pigment in the seat of the eruption, which may be for a time more or less anæesthetic ; sometimes, however, they pass away, and leave no apparent trace of their former existence. Several months may elapse between successive crops of these red blotches, but with each return there is an increased liability to permanent tissue-changes in the true skin.

Among the prodromata, belong occasional outbreaks of bulla, like those of pemphigus, which may last for many months before the regular leprosy sets in. This eruption is distinguished from idiopathic pemphigus by the fact that bullæe usually appear singly and suddenly, one healing before another shows itself. They vary in size from a nut to a hen's egg, and generally break a few hours after they appear. During the febrile attacks, there is often an insatiable thirst.

This drawing has been made for me by my friend and pupil $\mathrm{Mr}$. David Hepburn, from a case of leprosy now under my care at Middlesex Hospital, and shows the disease in an early stage of its development.

1. Macular Leprosy.-After a longer or shorter premonitory stage (or sometimes without any at all), permanent macula appear in the skin; the spots assume various forms, of which the following are the most common and characteristic. They consist of more or less circular spots, varying in size from half-a-crown to the palm of the hand. The edges are a little raised and of a reddish colour, the redness disappearing under pressure. The centre is slightly depressed, pale, dry, and sometimes white and shining. The tendency of these spots is to spread at the circumference. The hairs on the patch are more or less atrophied, and may become grey or perfectly white, and the skin in the centre loses its sensibility. After a time, the spots shrivel and become atrophied, either uniformly or in patches, so as to present an appearance of many small, shallow, white, scar-like depressions. The areas affected sometimes become blended, and then form large surfaces of altered skin.

2. A more common appearance than the one above described is that of discoloured patches, which sometimes present a raised margin, and often occupy a large tract of skin, which becomes covered with a dark pigmentation. The centre of these may be of a lighter shade, or even white, and thus irregular rings and markings are produced. These white spots may again become brown, in consequence of fresh pigmentary deposits. In most of them, sensation is impaired.

Danielssen, speaking of what he calls the "permanently eruptive stage", says, "the discolorations no longer disappear under pressure ; their colour is more intense, the thickening of the corium more notable; and there will be no longer any retrogressions or disappearances of the eruption."

The various forms and appearances which macular leprosy assumes in the different stages of its progress, and in different individuals, hardly admit of a detailed description. They can only be fully realised by the inspection of a large number of cases.

II. AN fESTHETIC LEPROSY is sometimes a further development of the macular variety. At other times, the changes in the skin are so slight as to escape notice, until numbness over patches of otherwise healthy looking cutis first attracts attention. It is in anæsthetic leprosy that the eruption of bullæ, which I have already described, is most frequently seen. After the blebs have burst, they usually dry up and scale, leaving dark pigmented patches, or more commonly white spots, from the absence of pigment. Occasionally, however, instead of drying up, they form into ulcers, which subsequently slowly cicatrise, and give rise to thick, smooth, irregular scars. At first, the spots which remain after the disappearance or cicatrisation of the bullæ, may retain their normal sensibility, but sooner or later they all become anæsthetic. At the same time that these changes are going on, hyperasthesia may exist in healthy looking parts of the skin; and patients often complain of pricking and shooting pains in the fingers and toes, with jerkings and shakings of different parts of the body, so much so in some cases that they require to be fed. This hyperæsthesia, which may be either local or general, often lasts for months or even years, and causes great distress to the sufferer, who lies torpid in bed, because walking or even moving is attended with great pain. The handling things, moreover, causes all kinds of subjective sensations, such as burning, stabbing, and irregular reflex muscular action. Later on, the hyperæesthesia diminishes or disappears, and is followed by the characteristic feature of the disease, namely anæsthesia, which commonly, though not universally, developes in those parts of the skin which have been previously hyperasthetic, or the seat of abnormal pigmentation.

Thus we see that the pemphigus, maculæ, the hyperæsthesia and the anæsthesia, are all closely related, and follow each other in a kind of series. For example, a spot of the size of a crown may appear on the face, of a pale red tint, slightly swollen, and painful to the touch ; to this succeeds an alteration in the pigmentation of the part, so that the spot becomes white or brown, and at the same time its red edge advances, and forms a small hyperæsthetic zone around an inner anæs. thetic area; outside all, is healthy-looking skin. The anæsthesia, which is at first confined to one or two spots, may gradually irvade almost the whole surface of the body, and especially it may affect un. changed patches of skin.

The insensible parts do not generally correspond with the distribution of particular cutaneous nerves, but spread into the area of several nerve. trunks, or occupy one only partially; even in the midst of a large anæsthetic district, there may be sensitive islands. In some cases, the loss of sensation is so complete that patients may be severely burned without knowing it. Mr. Arthur Gordon, speaking of a visit that he paid to the Leper Hospital at New Brunswick, says : "One individual was pointed out to me whose hand and arm had been allowed to rest accidentally on a nearly red hot stove, and who had never discovered the fact until attention was arrested by the strong scent of the burning limb, which was terribly injured."

As the disease advances, atrophic changes occur in the skin and deeper 